\title{
The Interconnected Biosphere: Science at the Ocean's Tipping Points
}

\author{
BY JANE LUBCHENCO AND LAURA E. PETES
}

Remarks from the Eleventh Annual Roger Revelle Commemorative Lecture. This lecture was created by the Ocean Studies Board of the National Academies in honor of Dr. Roger Revelle to highlight the important links between ocean sciences and public policy. Jane Lubchenco, this year's speaker, was introduced by Senator John Kerry, and the lecture was held on March 2, 2010, at Baird Auditorium at the Smithsonian's National Museum of Natural History.

ABSTRACT. Advances in social and natural sciences provide hope for new approaches to restore the bounty and resilience of ocean ecosystems. From new interdisciplinary approaches and conceptual frameworks, to new tools-such as catch shares, ecosystem-based management, marine spatial planning, and marine reserves-to new insights into strategies for adapting to the impacts of climate change and designing resilient and effective institutions, new knowledge is beginning to inform policies and practices. This decade is a pivotal one for the future of the ocean. The confluence of local, regional, and global changes in the ocean-driven by stressors, including nutrient pollution, habitat loss, overfishing, and climate change and ocean acidification-is rapidly transforming many once bountiful and resilient ocean ecosystems into depleted or disrupted systems. Degraded ecosystems cannot provide key ecosystem services, such as production of seafood, protection of coastlines from severe storms and tsunamis, capture of carbon, and provision of places for recreation. The accelerating pace of change presents daunting challenges for communities, businesses, nations, and the global community to make a transition toward more sustainable practices and policies. In this paper, we highlight new interdisciplinary approaches, tools, and insights that offer hope for recovering the bounty and beauty of the ocean and the ongoing benefits that they provide to people.

\section{INTRODUCTION}

Numerous studies have documented the depletion and disruption of ocean ecosystems at local to global scales, the consequences of these changes to human well-being, and the need for new attitudes, policies, and practices to recover and sustain healthy ocean ecosystems and the variety of human activities that depend upon them (Pew Oceans Commission, 2003; US Commission on Ocean Policy, 2004; Millennium Ecosystem Assessment, 2005; United Nations Environment Programme,
2006). Depleted fisheries, endangered turtles and marine mammals, dead zones, bleached corals, and outbreaks of jellyfish, harmful algal blooms, and diseases are all symptoms of the population and ecosystem changes underway. These changes are the result of myriad interacting stressors, including overfishing, chemical and nutrient pollution, use of destructive fishing gear, climate change, ocean acidification, habitat loss, and introduction of invasive species. However, they also reflect the failure of current management and policy, as well as a lack of general awareness of the causes and consequences of depletion and disruption. The prospect of significantly more disruption from climate change and ocean acidification looms large and lends urgency to an already serious situation.

Many ocean ecosystems appear to be at a critical juncture. Like other complex, nonlinear systems, ocean ecosystems are often characterized by thresholds or "tipping points," where a little more 


\section{Roger Revelle}

For almost half a century, Roger Revelle was a leader in the field of oceanography. Revelle trained as a geologist at Pomona College and the University of California, Berkeley. In 1936, he received his PhD in oceanography from the Scripps Institution of Oceanography. As a young naval officer, he helped persuade the Navy to create the Office of Naval Research (ONR) to support basic research in oceanography and was the first head of ONR's geophysics branch. Revelle served for 12 years as the Director of Scripps (1950-1961, 1963-1964), where he built up a fleet of research ships and initiated a decade of expeditions to the deep Pacific that challenged existing geological theory.

Revelle's early work on the carbon cycle suggested that the sea could not absorb all the carbon dioxide released from burning fossil fuels. He organized the first continual measurement of atmospheric carbon dioxide, an effort led by Charles Keeling, resulting in a long-term record that has been essential to current research on global climate change. With Hans Suess, he published the seminal paper demonstrating the connection between increasing atmospheric carbon dioxide and burning of fossil fuels. Revelle kept the issue of increasing carbon dioxide levels before the public and spearheaded efforts to investigate the mechanisms and consequences of climate change.

Revelle left Scripps for critical posts as Science Advisor to the Department of the Interior (1961-1963) and as the first Director of the Center for Population Studies at Harvard (1964-1976). Revelle applied his knowledge of geophysics, ocean resources, and population dynamics to the world's most vexing problems: poverty, malnutrition, security, and education.

In 1957, Revelle became a member of the National Academy of Sciences to which he devoted many hours of volunteer service. He served as a member of the Ocean Studies Board, the Board on Atmospheric Sciences and Climate, and many committees. He also chaired a number of influential Academy studies on subjects ranging from the environmental effects of radiation to understanding sea-level change.

Photo credit: SIO Archives, UCSD change in a stressor can result in a sudden and precipitous loss of ecological functionality. Some marine systems have already crossed a threshold, resulting in changes, such as a rapid fishery collapse (Millennium Ecosystem Assessment, 2005; Biggs et al., 2009). Others may well be approaching tipping points. Actions taken now and in the coming decade will likely determine the future health of most, if not all, ocean and coastal ecosystems. In turn, the state of these ecosystems will affect economic and social well-being. Existing scientific knowledge is not being acquired or incorporated rapidly enough into public understanding or into management and policy decisions. This essay seeks to focus on some recent advances in social and natural sciences that are relevant to a transition toward more sustainable practices and policies. Some of the advances are beginning to be implemented but need to be scaled up; others have yet to be employed or translated into usable tools. New knowledge in high-priority areas is also needed.

The goal of this essay is to catalyze interest in using scientific knowledge to maximize the likelihood of achieving healthy, productive, and resilient coastal and ocean ecosystems and enabling a vibrant suite of sustainable human uses

Jane Lubchenco (jane.lubchenco@noaa. gov) is Under Secretary of Commerce for Oceans and Atmosphere and Administrator of the National Oceanic and Atmospheric Administration (NOAA), Washington, DC, USA. Laura E. Petes (laura.petes@noaa.gov) is an American Association for the Advancement of Science (AAAS) Science and Technology Policy Fellow, NOAA Climate Program Office, Silver Spring, MD, USA. 
of oceans and coasts. In the following pages, we (1) highlight new scientific understanding in the broad areas of ecosystem services, coupled natural and social systems, and resilience; (2) focus on a few promising tools and approaches to address the challenges ahead; and (3) describe areas for further work.

\section{ECOSYSTEM SERVICES LINK HUMAN WELL-BEING TO THE ENVIRONMENT}

Managed and unmanaged ecosystems provide the life-support systems for people and all life on Earth (Daily et al., 2000). Physical, chemical, and biological perturbations of the ocean, land, and atmosphere-especially over the last few decades-have significantly altered the functioning of ecosystems and thus the delivery of their life-supporting services (Vitousek et al., 1997; Lubchenco, 1998; National Research Council, 1999; Millennium Ecosystem Assessment, 2005; United Nations Environment Programme, 2006; Carpenter et al., 2009a). The Millennium Ecosystem Assessment (2005) documents the dependence of human well-being on healthy ecosystems, the global loss of ecosystem services, and the options for reversing this trend. In short, human well-being depends upon services provided by ecosystems, but human activities have so utterly transformed ecosystems and altered their functioning that $60 \%$ of ecosystem services are currently at risk (Millennium Ecosystem Assessment, 2005; United Nations Environment Programme, 2006). However, in most cases, viable options exist for recovering and sustaining the delivery of services.

Ecosystem services are the benefits provided by ecosystems; they result from interactions of plants, animals, and microbes with one another and with the environment. Services vary according to the type of ecosystem (e.g., coral reef, mangrove, kelp forest, open ocean). Each ecosystem provides multiple types of services: provisioning services, such as seafood; regulating services, such as coastal protection or climate regulation; cultural services, such as recreation; and supporting services, such as nutrient cycling and primary production (Table 1; Millennium Ecosystem Assessment, 2005).

For example, a mangrove ecosystem provides wood fiber, fuel, and nursery habitat for numerous species (provisioning services); it detoxifies and sequesters pollutants coming from upstream, stores carbon, traps sediment, and thus protects downstream coral reefs, and buffers shores from tsunamis and storms (regulating services); it provides beautiful places to fish or snorkel (cultural services); and it recycles nutrients and fixes carbon (supporting services).

Ecosystem functioning and the delivery of services are affected by changes in biodiversity, habitat fragmentation and conversion, climate change, and alterations to biogeochemical cycles. When an ecosystem is converted to another use, some services may be lost and others gained. For example, when mangroves are converted to shrimp ponds, airports, shopping malls, agricultural lands, or residential areas, food production, space for commerce or transportation, or housing services are obtained, but the natural services are lost. Similarly, when river direction and flow are modified to obtain navigation and flood-control services, the replenishment of coastal wetlands and barrier islands is diminished, resulting in loss

Table 1. Ecosystem services provided by the ocean. Provisioning, regulating, and cultural services provide direct benefits to humans; supporting services are necessary for the production of all other ecosystem services (Millennium Ecosystem Assessment, 2005; United Nations Environment Programme, 2006).

\begin{tabular}{|c|c|c|}
\hline $\begin{array}{c}\text { Provisioning } \\
\text { Seafood, habitat, fuel wood, } \\
\text { genetic resources }\end{array}$ & $\begin{array}{c}\text { Regulating } \\
\text { Climate regulation, disease and } \\
\text { pest regulation, coastal protection, } \\
\text { detoxification, sediment trapping }\end{array}$ & $\begin{array}{c}\text { Cultural } \\
\text { Aesthetic, spiritual, educational, } \\
\text { recreational }\end{array}$ \\
\hline Sutrient cycling, primary production \\
\hline
\end{tabular}


of habitat, nursery areas, carbon storage, and protection from storms. Typically, conversion or other alterations are implemented without consideration of the tradeoffs.

The importance of a service is often not appreciated until it is lost. Post Hurricane Katrina, residents of New Orleans speak openly about the need to restore barrier islands and coastal wetlands so they can function as "speed bumps" for hurricanes. This assertion is also borne out elsewhere: in the 2004 Indian Ocean tsunami, areas of India with intact mangroves suffered fewer losses of human lives and property than did areas where mangroves had been cleared, demonstrating the importance of the buffering capacity provided by these plants (Kathiresan and Rajendran,
2005). At the global scale, the loss of species from large marine ecosystems has led to a reduction in the ocean's capacity to provide food, improve water quality, and recover from disturbance (Worm et al., 2006).

Although people will readily articulate some of the benefits they derive from the ocean (Figure 1), they are usually unaware of many others, and they often miss the key points that most of those benefits depend on healthy ocean ecosystems and that these ecosystems are already degraded or threatened. Clearly, translating general scientific knowledge about the importance of ecosystem services into useful guidance and tools for decision makers is a high-priority challenge. Educating citizens and decision makers about the importance of services is necessary, but it is not sufficient without tools and information to translate that knowledge into practices and policies. Understanding, assessing, and measuring ecosystem services can be difficult (Carpenter and Folke, 2006; Carpenter et al., 2009a). Moreover, most of the research on ecosystem services has been conducted in terrestrial systems. In addition, ecosystem services need to be explicitly linked to socioecological scenarios to demonstrate how ecosystems benefit humans (Tallis and Kareiva, 2006).

The utility of understanding and communicating tradeoffs was demonstrated in the Catskill Mountains, where changes in watershed management to improve water quality for New York City were based on knowledge of the

\section{Citizens Want To See...}
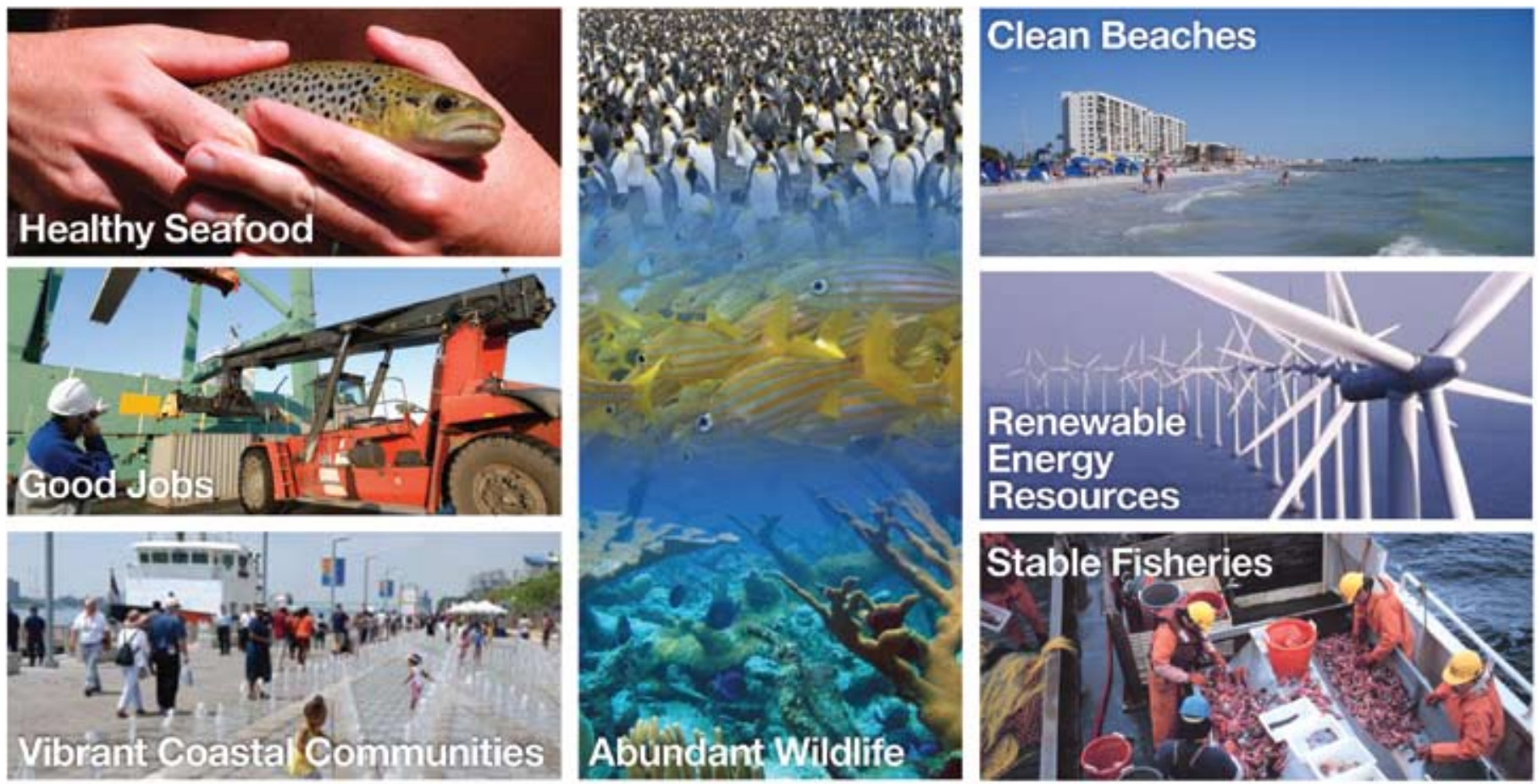

...For Generations and Generations

Figure 1. Ecosystem services as articulated by the general public. Photos used with permission from the National Oceanic and Atmospheric Administration 
value provided by ecosystem services. In 1996, when drinking water quality fell below Environmental Protection Agency standards due to degradation of the watershed, the City of New York faced the dilemma of whether to invest in Catskill watershed ecosystem restoration (\$1-1.5 billion) or a water filtration plant (\$6-8 billion; Chichilnisky and Heal, 1998). The decision to invest in "natural capital" (in the form of ecosystem restoration) saved money and restored both the ecosystem services of interest (water purification and filtration) as well as other services, such as carbon storage and opportunities for recreation, none of which would have been obtained through building a new filtration plant (Heal et al., 2001).

There are several emerging scientific efforts to enhance our understanding of the benefits that humans obtain from ecosystems and to apply that knowledge in decision making. The challenge of determining, measuring, and communicating the values of ecosystem services is being addressed through efforts such as the Natural Capital Project (http:// www.naturalcapitalproject.org), a partnership among Stanford University, The Nature Conservancy, and the World Wildlife Fund to develop tools for facilitating incorporation of natural capital (i.e., valuation of ecosystem services) into decision making. Their first tool, InVEST (Integrated Valuation of Ecosystem Services and Tradeoffs), can model and map the delivery, distribution, and economic value of ecosystem services into the future. InVEST allows users to visualize the impacts of their potential decisions, which enables identification of tradeoffs among environmental, economic, and social benefits. This tool has already been applied successfully using stakeholderdefined scenarios to predict changes in land use and associated tradeoffs in the Willamette Valley, Oregon (Nelson et al., 2009). Although InVEST was initially focused on terrestrial ecosystems, it is now being applied to coastal and marine ecosystems to provide maps and be placed on incorporating social data and projections of social distributional effects into ecosystem services valuation in order to determine and maximize win-win outcomes (Tallis and Polasky, 2009) and on obtaining basic information about the fundamental workings of coupled human-natural systems (Carpenter et al., 2009a).

\section{$\zeta S_{\text {THE ACCELERATING PACE OF CHANGE PRESENTS }}$ DAUNTING CHALLENGES FOR COMMUNITIES, BUSINESSES, NATIONS, AND THE GLOBAL COMMUNITY TO MAKE A TRANSITION TOWARD MORE SUSTAINABLE PRACTICES AND POLICIES.}

projections of ecosystem services under different management alternatives for issues, such as tradeoffs associated with large-scale implementation of desalination plants in California (Ruckelshaus and Guerry, 2009). Marine InVEST offers a promising new approach for incorporating scientific information about ecosystem services into decision making and resource management.

Effective valuation of ecosystem services requires acknowledging that global social change and global environmental change interact with one another (Young et al., 2006). When facing decisions that affect ecosystem services, tradeoffs between social values and environmental outcomes can either be win-win, win-lose, or lose-lose, and the challenge is to develop solutions that are win-win, where both social and environmental goals are achieved (Tallis et al., 2008). Increased emphasis should
One major obstacle to ecosystem services valuation is that detailed information on how people benefit from specific services at scales useful for decision making is currently sparse (Turner and Daily, 2008). In addition, because ecosystem services valuation is a relatively new field of science, there are few examples of "lessons learned" to inform new efforts. Databases are a useful tool for providing centralized, publicly accessible sources of information. The Natural Capital Database (http://www. naturalcapitalproject.org/database. $\mathrm{html}$ ), currently under development, will be a compilation of strategies and outcomes from conservation projects that have focused on ecosystem services. This information clearinghouse will allow decision makers and managers to learn lessons from previous efforts that they may be able to apply to their own planning processes. 


\section{UNDERSTANDING COUPLED}

\section{SOCIAL-NATURAL SYSTEMS AS}

COMPLEX ADAPTIVE SYSTEMS

Until recently, studies of social systems and of natural systems proceeded independently of one another. Novel interdisciplinary approaches have recently emerged for studying human and natural systems as coupled systems (Liu et al., 2007; Berkes et al., 2008; Ostrom, 2009). These efforts seek to understand the interconnectedness of people and ecosystems, the bases of decision making, and perceptions of risk, equity, and scale (Figure 2; Ostrom et al., 1999; Dasgupta et al., 2000; Dietz et al., 2003; Kinzig et al., 2003; McLeod and Leslie, 2009a). Interdisciplinary approaches will enable the changes in practices and policies needed to use ecosystems sustainably and to facilitate human wellbeing (Figure 3).

Insights from other scientific areas are also informing the understanding of coupled human and natural systems, specifically the study of complex adaptive systems. These systems are defined by the fact that dynamics of interactions at small scales affect macroscopic system dynamics, which then feed back to impact the small scales (Levin, 1998). Across numerous types of complex adaptive systems, the same key features appear necessary for a system to be robust and resilient (i.e., to have the capacity to absorb stresses and continue functioning; Levin and Lubchenco, 2008): modular structure, redundancy of modules, diversity and heterogeneity of modules, and tight feedback loops (Levin, 1999). Tradeoffs exist between elements, and therefore, optimum resilience may be obtained at intermediate levels of these components (Levin, 1999).

Evidence suggests that ecosystems with higher diversity are more resilient

\section{COUPLED SOCIAL-ECOLOGICAL SYSTEMS}

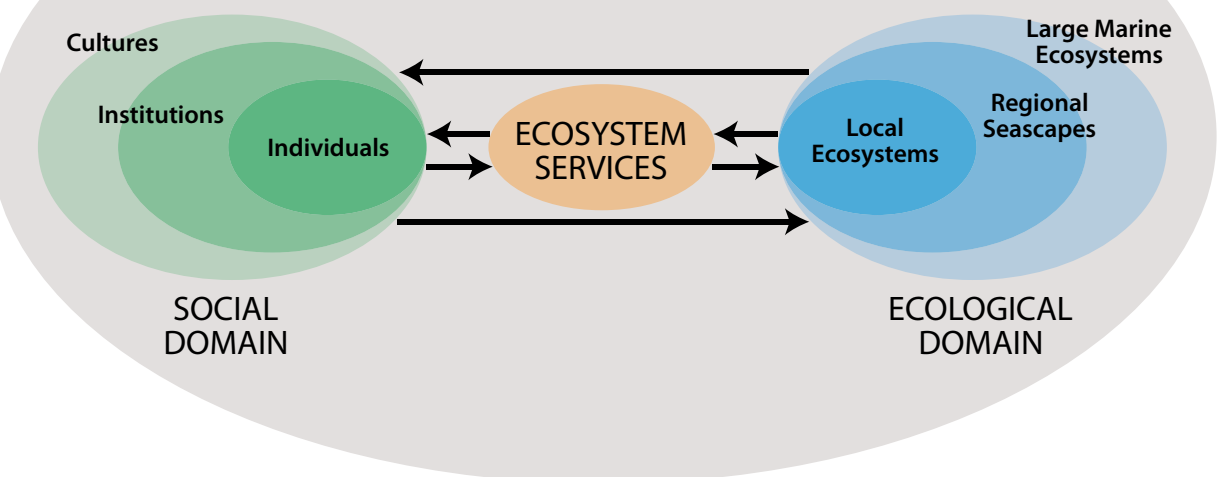

Figure 2. Schematic of nested interactions between human and ecological systems (McLeod and Leslie, 2009b). Social and ecological domains interact over multiple geographic and organizational scales; understanding connections across scales is critical to the long-term success of ecosystem-based management efforts. Ecosystem services represent a key connection between domains, and the flow of services is affected by both social and ecological factors. Used with permission from Island Press

(Millennium Ecosystem Assessment, 2005). This has been documented for areas that are recovering from species loss: as diversity increases, valuable ecosystem services are restored, leading to higher resilience (Worm et al., 2006). New interdisciplinary efforts, such as the Resilience Alliance (http://www.resalliance.org) and the Forum on Science and Innovation for Sustainable Development (http://www. sustainabilityscience.org), are actively exploring the dynamics of socioecological systems in order to provide a foundation for sustainability. These efforts acknowledge that the study of ecosystem resilience is complex and requires interdisciplinary tools, creative approaches (e.g., network analyses; Janssen et al., 2006), and collaborations (Schellnhuber et al., 2004; Walker and Salt, 2006; Carpenter et al., 2009b; Leslie and Kinzig, 2009). New approaches that would enhance the capacity of management systems to adapt quickly in response to changing conditions would be beneficial (Carpenter and Brock, 2008).

Incorporating social sciences into decision making and adaptive management is an arena where significant new advances have begun. The 2009 Nobel Prize in Economics to Elinor Ostrom explicitly recognizes the importance of interdisciplinary approaches, the key role that institutions play, and the multiple scales of decision making relevant to managing common-pool resources (e.g., Ostrom, 2009). Organization of human institutions can have a large impact on ecosystem resilience and sustainability; therefore, participatory processes that facilitate experimentation, learning, and change will benefit 




Figure 3. Human and natural systems are inextricably linked. (a) Governor Deval Patrick of Massachusetts announces the Oceans Act of 2008 to initiate the development of a comprehensive spatial plan. (b) Exploring the rocky intertidal zone of the Olympic Coast National Marine Sanctuary. (c) Fishing for halibut in Sitka, Alaska, where a catch share program has been in place for a decade. (d) Louisiana school children work to restore wetlands through a NOAA Bay-Watershed Education and Training grant awarded to the Louisiana State University Coastal Roots Program. Photo a used with permission from the Massachusetts Governor's Office. Photos b, $c$, and $d$ used with permission from the National Oceanic and Atmospheric Administration

planning efforts (Dietz et al., 2003).

Because changes in environmental and social conditions are occurring, institutions must also be prepared to change, a core tenet of adaptive management (Dietz et al., 2003). This raises the need to design strategies and institutions for integrating incomplete knowledge with experimental action into programs of adaptive management and social learning (National Research Council, 1999) and to grow capacity to manage the ocean and coasts sustainably (National Research Council, 2008).

In addition, it is important to understand what scientific information best meets the needs of decision makers and managers attempting to prepare for and respond to environmental change.
Information users must be able to articulate their needs to the scientific community, who can in turn provide them with information that fits the scales and topics necessary for decision making. These interactions will require the creation of new relationships, institutions, and channels of communication, which social science research can help to inform. Studies on strategies for successful communication of complex scientific issues and uncertainty will also benefit these ongoing dialogues. A better understanding of social, cultural, and economic barriers to adaptive action and management is needed. Identifying barriers and designing strategies to eliminate them when possible will allow for action at all scales of governance.
EMERGING APPROACHES AND TOOLS TO ENHANCE ECOSYSTEM RECOVERY, RESILIENCE, AND SUSTAINABILITY

As emphasized by the Pew Oceans Commission (2003), the current problems in the ocean are both a failure of understanding and a failure of governance. Most people are unaware of the current state of the ocean or that the benefits they seek from the ocean are at risk unless changes are made. The mindset that the ocean is so vast and bountiful that it is infinitely resilient persists. Likewise, few are aware of how their individual choices affect the ocean or other people. Providing credible information from trusted sources will be critical for raising awareness about the need to improve practices and policies. In other words, the scientific advances described above need to be incorporated into public understanding.

This knowledge must also be translated into new tools, guidelines, and approaches for communities, interest groups, decision makers, and resource managers. A significant shift is underway in approaches to ocean management (Table 2), creating more demand for practical guidance and tools. Some of the new tools and approaches have already been mentioned, such as the Natural Capital Project's InVEST tool and coupled social-natural approaches to decision making. Others include integrated ecosystem assessments, ecosystem-based management (EBM), marine spatial planning (MSP), catch shares, nutrient-trading schemes, biodiversity banks, marine protected areas (MPAs) and marine reserves, and decision-support and visualization tools. Four of these tools are described below. 
Table 2. A shift in approaches to management is underway for coastal and marine ecosystems.

\begin{tabular}{|l|l|}
\hline Historical Approach & New Approach \\
\hline Short-term perspective & Long-term and evolutionary perspectives \\
\hline Single-sector focus & Multi-sector focus \\
\hline Natural science approach & Coupled natural and social science approach \\
\hline Single-species management & Ecosystem-based management \\
\hline Focus on delivery of products & Focus on maintaining ecosystem resilience and delivery of ecosystem services \\
\hline Greater use of fines & Greater use of incentives \\
\hline Regulation of effort & Regulation of outcome \\
\hline Command and control, centralized, top-down regulation & Top-down plus bottom-up decision making; more local control \\
\hline Reactive & Anticipatory and precautionary \\
\hline Static & Adaptive \\
\hline
\end{tabular}

\section{Marine Ecosystem-Based}

Management (EBM)

EBM simply means taking a place-

based, ecosystem approach to management, with the goal of sustaining the long-term capacity of the system to deliver ecosystem services (Rosenberg and McLeod, 2005). Doing so requires synthesizing and applying knowledge from social and natural sciences.

EBM is different from traditional approaches that usually focus on a single species, sector, activity, or concern. In contrast, EBM considers the cumulative impacts of different sectors and the connections between people and ecosystems, as well as the connections among the different components of the ecosystem (Figure 4). Although many EBM concepts have been codified only recently (McLeod et al., 2005), they are actively employed in multiple ecosystems around the world. Recent advances in understanding and practicing EBM are summarized in McLeod and Leslie (2009a).

\section{Marine Spatial Planning (MSP)}

MSP, also called coastal and marine spatial planning, is an EBM tool for minimizing conflicts among users and reducing impacts on ecosystem functioning. Increasing demands on ocean space for diverse uses, including tourism, recreation, fishing, shipping, national security, oil and gas exploration, and wave and wind energy, have led to more and more conflicts among users, as well as additional impacts on already stressed ocean ecosystems (United Nations Environment Programme, 2006; Douvere, 2008). MSP is a process that enables integrated, forward-looking decision making through an ecosystembased, spatially explicit approach (Ehler and Douvere, 2007). Spatial planning has been practiced on land for centuries, as humans have determined how to allocate specific areas for multiple uses, including forestry, conservation, development, and agriculture.

The concept of zoning in the ocean is a relatively new idea. The first comprehensive MSP was developed in the 1980s for the Great Barrier Reef Marine Park in Australia. Specific areas are zoned for different uses, including fishing and tourism, and other areas are designated as fully protected, helping to minimize user conflicts and ecosystem impacts (Douvere, 2008). Because of the interdependency of human and natural systems, the MSP process is most successful when it involves broad participation by stakeholder groups, scientists, and managers (Pomeroy and Douvere, 2008). In addition to consideration of human uses, it is important for planners to understand the biological communities and the key processes that maintain them in order to create plans that maximize ecosystem resilience (Crowder and Norse, 2008).

Efforts are currently underway to develop marine spatial plans for the United States. On December 14, 2009, President Obama's Interagency Ocean Policy Task Force released an interim framework for effective coastal and 
marine spatial planning. Two weeks later, the Commonwealth of Massachusetts became the first US state to release a comprehensive ocean management plan for its 1,500-mile coastline (Figure 3a). Other states and nations are pursuing use of this tool as a vehicle for more holistic management of ocean resources and ecosystems.

\section{Marine Protected Areas (MPAs) and Reserves}

MPAs provide a complementary tool for protecting habitat, biodiversity, and ecosystem functioning (e.g., Halpern et al., in press). MPAs are areas of the ocean that are managed for a conservation benefit. This tool provides an ecosystem- and place-based approach to management, as opposed to a speciesbased approach. MPAs may be used alone or as part of an MSP framework.

Fully protected (also called "no-take") marine reserves are a type of MPA that are completely protected from all extractive and destructive activities (Lubchenco et al., 2003). Marine reserves currently constitute $<1 \%$ of the global ocean (Wood et al., 2008). Benefits of marine reserves include habitat protection, biodiversity conservation, enhancement of ecosystem services, recovery of overexploited stocks, export of individuals outside the reserve, insurance against environmental uncertainty, and sites for scientific research, education, and recreation (Allison et al., 1998). Scientific analyses of the hundreds of no-take marine reserves around the world provide compelling evidence that they do indeed protect biodiversity and habitats (Gaines et al., in press a). Density, diversity, biomass, and size of organisms are higher inside reserves as opposed to outside (Figure 5; Halpern, 2003; Partnership for Interdisciplinary Studies of Coastal Oceans, 2007; Hamilton et al., in press). On average, these benefits are rapid (often occurring within one to three years) and long-lasting (Halpern and Warner, 2002). However, not all species respond rapidly, and the rates at which populations change depend on life histories and the availability of colonists (Babcock et al., in press), as well as social factors (Pollnac et al., in press).

Marine reserves provide a unique mechanism for protecting large-bodied individuals of fish and invertebrates. Large females (otherwise known as "big, old, fecund females" or BOFFs) have much greater reproductive potential than do smaller females (Figure 6) and are understood to be especially important for sustaining populations. Protection of BOFFs may also help to counter the negative evolutionary impacts of fishing that result in reproduction at smaller sizes (Baskett et al., 2005), and, in some cases, the distortion of size structure and social structure for fish that are sequential hermaphrodites.

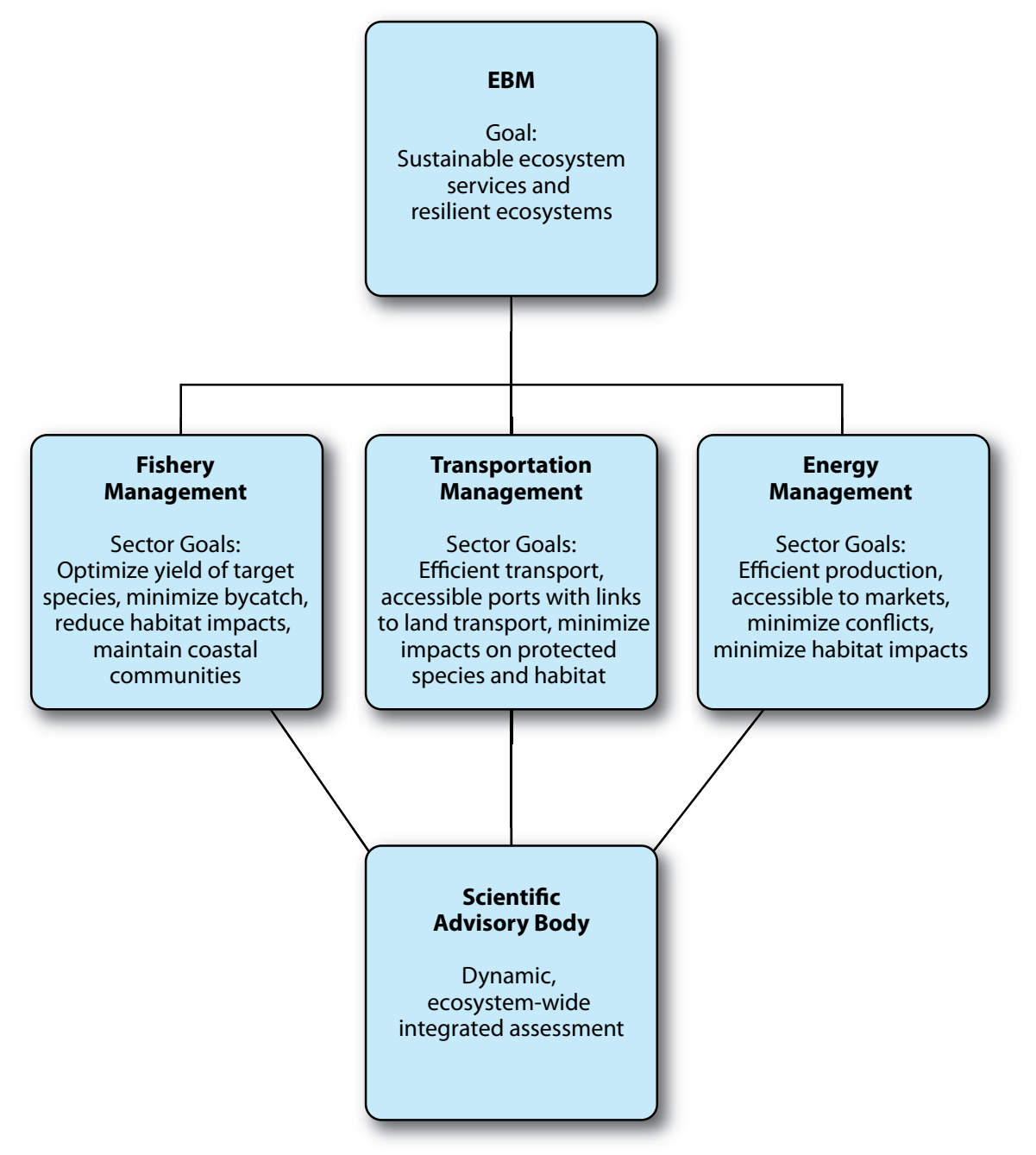

Figure 4. Framing ecosystem-based management (EBM) goals across sectors (modified from Rosenberg and Sandifer, 2009). Used with permission from Island Press 


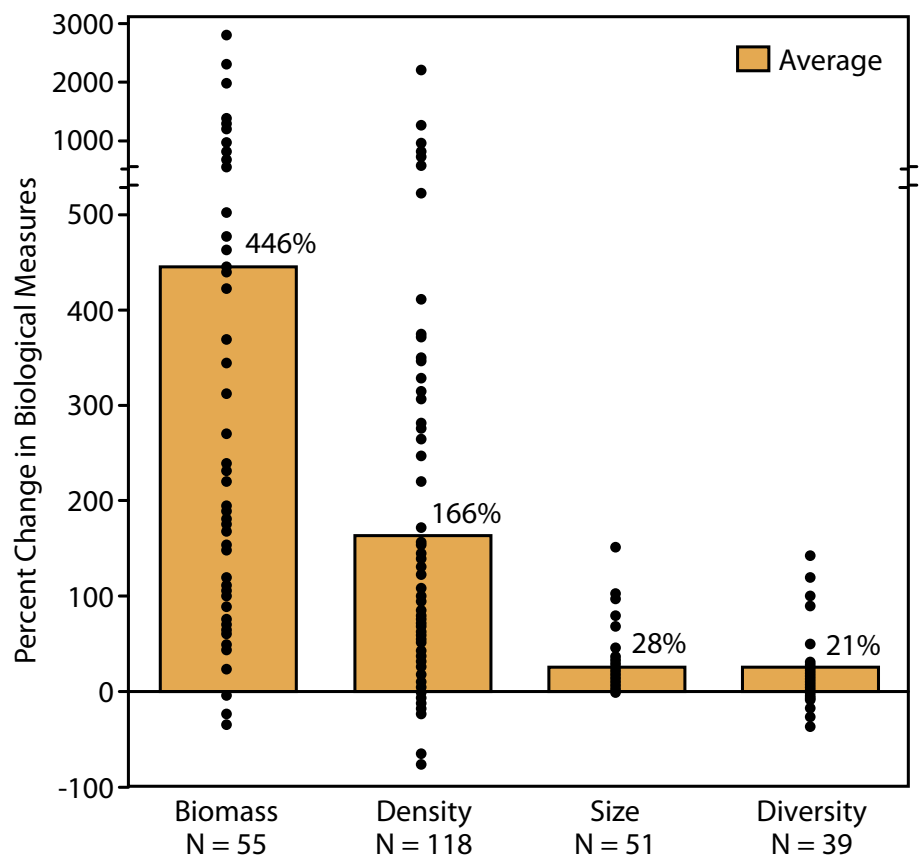

Figure 5. Impact of no-take marine reserves on biomass, density, size, and diversity of species inside of a reserve. Used with permission from the Partnership for Interdisciplinary Studies of Coastal Oceans; data from Lester et al. (2009)
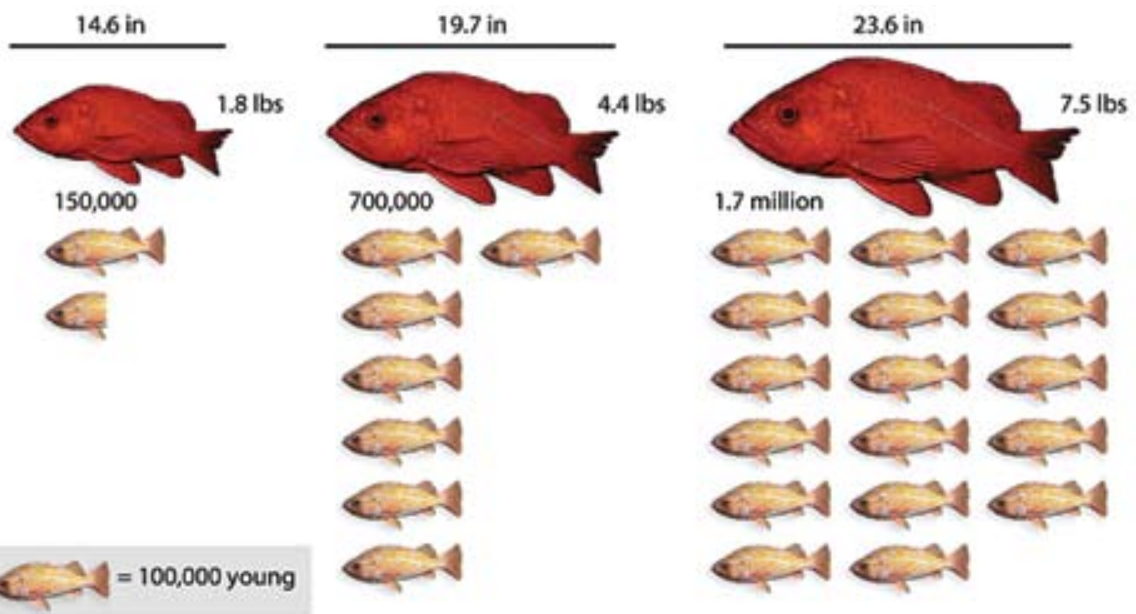

Figure 6. Relationship of number of young produced to body size of fish for vermillion rockfish. A 23-inch vermillion rockfish produces 17 times more young than it did when it was 14 inches long. Used with permission from the Partnership for Interdisciplinary Studies of Coastal Oceans; data from Love et al. (1990)

Productivity within marine reserves also leads to "spillover"- the migration of animals from inside the reserve to the outside-potentially enhancing commercial and recreational fisheries surrounding the protected area or contributing to recovery of depleted fisheries (Roberts et al., 2001; Partnership for Interdisciplinary Studies of Coastal Oceans, 2007). For example, coastal areas surrounding the Merritt Island, Florida, reserve exhibited a rapid increase in the number of world-recordsized black drum, red drum, and spotted sea trout once the fully protected area was established (Roberts et al., 2001).

Reproduction within reserves produces young that may be transported by ocean currents outside the reserve. This "export" of larvae is more difficult to quantify than "spillover" of juveniles or adults, but both processes transport benefits from inside a reserve to the surrounding areas. A network of marine reserves, which is a set of reserves separated by non-reserve waters but connected by the movement of young, juveniles, or adults, can be designed to maximize transport of benefits to the outside (McCook et al., in press; Pelc et al., in press). Because of spillover, export, and other benefits provided by reserves, optimal fisheries harvest occurs when some areas of a region are temporarily or permanently closed (Costello and Polasky, 2008). Planning and implementation of marine reserve networks are facilitated by access to biological and socioeconomic information (GrorudColvert et al., in press; Smith et al., in press). The availability of high-quality spatial information on the location of fish populations allows for spatial optimization in the implementation of marine reserve networks that lead to increased profit margins for surrounding fisheries (Costello et al., in press; Gaines et al., in press b). For all of these reasons, no-take marine reserves and MPAs are increasingly seen as useful tools in a larger strategy to protect and restore coastal and ocean ecosystems. 


\section{Catch Shares}

Catch shares provide an alternative to traditional fishery management by incorporating new understanding from social and economic sciences. Instead of individual commercial fishermen being incentivized by the "race to fish" to outcompete others, rights-based fisheries' reforms offer an alternative solution (Hilborn et al., 2005). In lieu of industry-wide quotas, fishermen are allocated individual quotas, referred to as "catch shares" of the total allowable catch, and the goal is to provide fishermen and communities with a secure asset in order to create stewardship incentives (Costello et al., 2008). Catch shares thus align economic and conservation incentives. They also hold fishermen accountable for adhering to the rules.

The concept of catch shares, pioneered in Australia, New Zealand, and Iceland, has now been implemented for hundreds of fisheries throughout the world. Effectiveness of catch shares was documented in a global analysis of over 11,000 fisheries. Results indicated that implementation of catch shares can halt, and even reverse, trends toward widespread fishery collapse (Figure 7; Costello et al., 2008; Heal and Schlenker, 2008). This evidence suggests that catch shares offer a promising tool for sustainable fisheries management.

To date, 12 fisheries in the United States have adopted this management approach. The results have been impressive: sustainable fisheries, improved economic performance of the fishery, decreased environmental impact, and increased safety at sea. For example, in Alaska's halibut (Figure 3c) and sablefish fisheries, the length of the fishing season was extended from less than a week to eight months per year, bycatch dropped by $80 \%$, and safety improved sharply (Redstone Strategy Group LLC and Environmental Defense Fund, 2007). In the Gulf of Mexico's red snapper fishery, commercial overfishing ended for the first time in decades, fishermen are receiving higher dockside prices for their catch and reducing costs as they are able to better plan their trips, and discards have decreased by $70 \%$ (Redstone Strategy Group LLC and Environmental Defense Fund, 2007). Catch shares are not necessarily suitable for every fishery, but they appear to hold promise for many.

\section{Future Possible Tools}

Other tools seem ripe for development but do not yet exist. One is a nutrienttrading scheme to decrease the flow of excess nutrients from agricultural and livestock areas into coastal waters. Dead zones (areas of low oxygen) in coastal oceans have spread exponentially since the 1960s as a result of nutrient runoff due to changes in agricultural and landuse practices; dead zones now occur over a total area of $245,000 \mathrm{~km}^{2}$ (Diaz and Rosenberg, 2008). Fertilizer use in the Mississippi River watershed, which drains $41 \%$ of the continental United States, leads to a severe, seasonal dead zone in the Gulf of Mexico that extends across 20,000 km² (Rabalais et al., 2002). One proposed approach for combating excess nitrogen input might be the establishment of cap-and-trade policy for nitrogen, where a limit would be set on nitrogen input for each region (Socolow, 1999), with regions able to trade quotas. A similar approach was successfully used by the Environmental Protection Agency

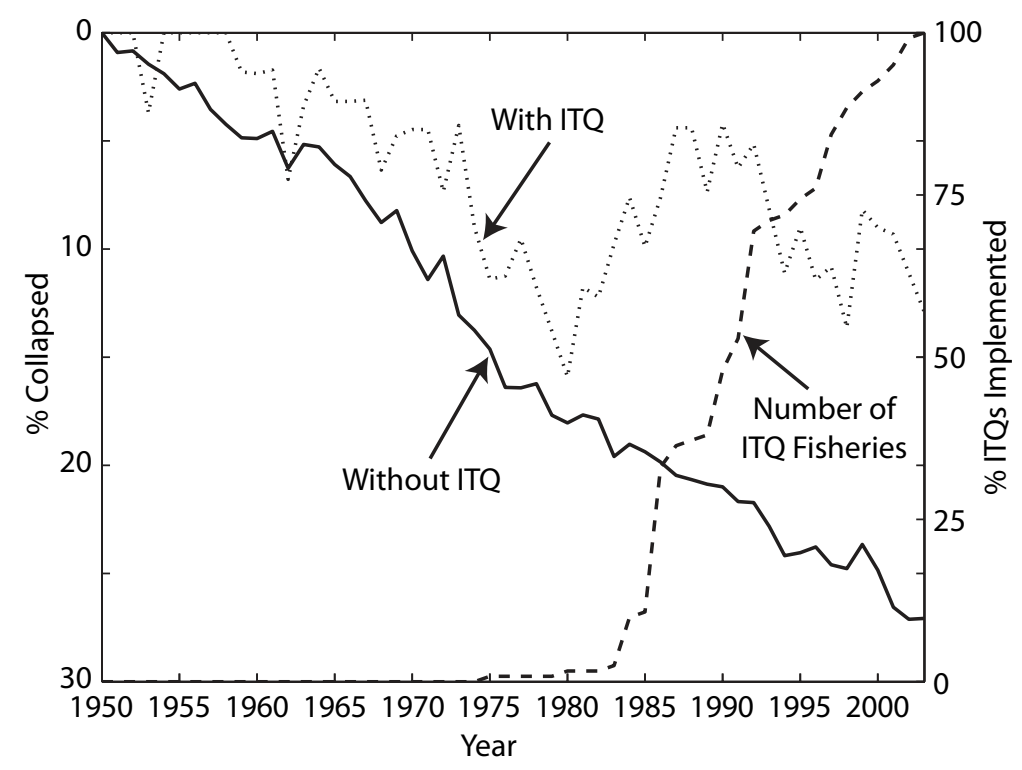

Figure 7. Percentage of fisheries collapsed (left $y$-axis) without (solid line) and with (dotted line) catch share management using the Worm et al. (2006) collapse threshold of $10 \%$ of historical maximum (modified from Costello et al., 2008). Individual transferable quotas (ITQs) are a form of catch shares. The number of catch share fisheries increases through time (right $y$-axis and dashed line). Used with permission from the American Association for the Advancement of Science 
under the Acid Rain Program to cap emissions of sulfur dioxide to reduce the occurrence of acid rain. This program was so effective that sulfur dioxide reductions were achieved at significantly lower costs and at much faster rates than originally estimated.

Another potentially useful tool would involve better analytical methods for detecting an approaching ecological threshold or tipping point in time to avert potential disaster (e.g., a fishery collapse). Biggs et al. (2009) provide an example of such an early-warning indicator. The lack of relevant, long-term data sets may present considerable challenges in utilizing these tools; therefore, efforts to further develop them will need to occur in parallel with (and should inform the development of) improved monitoring efforts. In addition, the utility of such indicators will rest upon the adaptive capacity of management to avert the shift-both the ability of the suite of ecosystem services requires protecting the functioning of ecosystems. Integrated ecosystem assessments that elucidate how the different social and natural components interact provide a decision-making framework. Placebased, ecosystem-based, and adaptive management approaches are essential. New tools to facilitate understanding of and decisions about tradeoffs will be key. In short, effective management of coastal and marine ecosystems will require forward-thinking, holistic, and ecosystem-based approaches that involve users, managers, and scientific experts.

\section{CHALLENGES AHEAD}

Continuing to educate and engage citizens, provide information to guide decision making, and develop and implement new tools and approaches based on the more holistic understanding described above will undoubtedly bring significant benefits. For those resilient institutions and management structures. This will also require significant advances in ecosystembased science, ecosystem services, and resilience from a coupled human-natural system perspective.

In addition, information is not always available at the relevant spatial scale for management. For example, the majority of climate change scenarios have been developed for the global scale, but most of the impacts will be felt at local to regional scales. This mismatch of scales makes it difficult for managers to incorporate climate information into their planning processes. Similarly, effective, sustainable management of large-scale resources (e.g., large marine ecosystems) requires collaboration among international, national, regional, state, and local levels, which creates challenges (Ostrom et al., 1999). The need to address problems at the local to regional scale associated with shared global resources is increasing. Globalization is occurring throughout many of our coupled human-natural systems, leading to increased connectedness, with both positive and negative results (Young et al., 2006). A diversity of scales is necessary for effective, resilient management; by building on local and regional institutions to focus on global problems, the likelihood of success can be increased (Ostrom et al., 1999). The focus on understanding impacts of climate change on regions (US Global Change Research Program, 2009) is leading to increased attention towards the ability of climate models to resolve regional scales.

Both climate change and ocean acidification are likely to transform coastal and ocean species, ecosystems, and ecosystem services. Priority should be 
given to understanding the likely impacts of climate change and ocean acidification, as well as ways to ameliorate those impacts. Given the rapid pace at which ecosystems are changing, "learning by doing" becomes more difficult because past lessons no longer accurately predict the future (Ostrom et al., 1999).

Even though today's challenges are already substantial, climate change and ocean acidification will interact with and exacerbate the other drivers of change. Hence, to be relevant and useful, management and policy must focus on tomorrow's coupled human-natural systems, not today's or yesterday's. Doing so is not easy but not impossible. Likely keys to success include the following approaches:

- Avoiding irreversible changes (such as extinctions)

- Managing for resilience

- Managing with the expectation of surprises

- Creating flexible institutions with capacity to adapt rapidly

- Preserving as much biodiversity (genetic, species, and habitat) as possible

- Developing rules of thumb for managers in lieu of precise targets

- Minimizing impacts from stressors over which there is more immediate control

- Sharing information and lessons via learning networks

- Investing effort in scientific research to provide knowledge for the above strategies

- Supporting monitoring and analysis to guide management and policy decisions

In short, these strategies fall into two categories: (1) making better use of existing information, and (2) acquiring new knowledge that would enhance more sustainable practices and policies. Incorporating climate change and ocean acidification adaptation strategies into management and policy decisions provides a useful way to integrate a number of the abovementioned approaches.

\section{CONCLUDING REMARKS}

Our future depends upon maintaining healthy ocean and coastal ecosystems and healthy human communities. Both are in flux, and each is coupled to the other. Ecosystem services link ecosystems to human well-being and provide a focus for understanding, policy, and management. Awareness that natural systems can undergo rapid change once a tipping point is reached lends urgency to the need for embracing novel tools and approaches, scaling up their use, and creating new knowledge, information, and tools.

Global threats to our coastal and marine ecosystems are rapidly increasing. We are currently operating in a "no analogue" state, in which human activities have driven global environmental change to a point that has never before been observed (Steffen et al., 2004). Biodiversity is declining, our natural resources are being depleted, and habitats are being destroyed. Along with these changes come the losses of valuable ecosystem services on which humans depend.

In addition to rapid shifts in ecosystems, social systems can also undergo rapid change once a tipping point is reached. Knowledge that rapid societal shifts occur can provide hope that successes in some places can be quickly adopted and implemented. The plethora of new advances and effective tools, successes at the local level, and engagement of citizens, businesses, and scientists around the world provide impetus for further engagement and hope that these efforts will succeed in transitioning to more sustainable practices and policies.

Priority actions include educating citizens and policymakers about the benefits of new approaches, strengthening interdisciplinary approaches to problem solving, reducing the stressors over which we have direct control (e.g., fisheries management, pollution, invasive species), reducing emission of greenhouse gases to slow down the rates of climate change and ocean acidification, protecting as much biodiversity as possible, and managing for ecosystem resilience. Holistic strategies for engaging stakeholders and for preserving or restoring ecosystem functioning and resilience are critical to success. Momentum is building, informed by scientific advances and public involvement. It's time to "seas the day."

\section{ACKNOWLEDGEMENTS}

We would like to thank the National Academies Ocean Studies Board, particularly Jodi Bostrom, Don Boesch, Pamela Lewis, and Susan Roberts, for organizing the Roger Revelle Lecture; the Smithsonian's National Museum of Natural History for hosting the event; and Senator John Kerry for providing a dynamic introduction to the lecture. Thanks to the Roger Revelle Lecture sponsors for their generous support. Logistical support from Frank Parker and figure design assistance from Mike Walker are also greatly appreciated. 四 


\section{REFERENCES}

Allison, G.W., J. Lubchenco, and M.H. Carr. 1998. Marine reserves are necessary but not sufficient for marine conservation. Ecological Applications 8(1):S79-S92.

Babcock, R.C., N.T. Shears, A.C. Alcala, N.S. Barrett, G.J. Edgar, K.D. Lafferty, T.R. McClanahan, and G.R. Russ. In press. Decadal trends in marine reserves reveal differential rates of change in direct and indirect effects. Proceedings of the National Academy of Sciences of the United States of America.

Baskett, M.L., S.A. Levin, S.D. Gaines, and J. Dushoff. 2005. Marine reserve design and the evolution of size at maturation in harvested fish. Ecological Applications 15(3):882-901.

Berkes, F., J. Colding, and C. Folke, eds. 2008. Navigating Social-Ecological Systems: Building Resilience for Complexity and Change. Cambridge University Press, Cambridge, UK, 416 pp.

Biggs, R., S.R. Carpenter, and W.A. Brock. 2009. Turning back from the brink: Detecting and impending regime shift in time to avert it. Proceedings of the National Academy of Sciences of the United States of America 106:826-831.

Carpenter, S.R., and W.A. Brock. 2008. Adaptive capacity and traps. Ecology and Society 13(2):40.

Carpenter, S.R., and C. Folke. 2006. Ecology for transformation. Trends in Ecology and Evolution 21(6):309-315.

Carpenter, S.R., H.A. Mooney, J. Agard, D. Capistrano, R.S. DeFries, S. Díaz, T. Dietz, A.K. Duraiappah, A. Oteng-Yeboah, H.M. Pereira, and others. 2009a. Science for managing ecosystem services: Beyond the Millennium Ecosystem Assessment. Proceedings of the National Academy of Sciences of the United States of America 106:1,305-1,312.

Carpenter, S.R., C. Folke, M. Scheffer, and F. Westley. 2009b. Resilience: Accounting for the noncomputable. Ecology and Society 14(1):13.

Chichilnisky, G., and G. Heal. 1998.

Economic returns from the biosphere. Nature 391:629-630.

Costello, C., and S. Polasky. 2008. Optimal harvesting of stochastic spatial resources. Journal of Environmental Economics and Management 56:1-18.

Costello, C., S.D. Gaines, and J. Lynham. 2008. Can catch shares prevent fisheries collapse? Science 321:1,678-1,681.

Costello, C., A. Rassweiler, D. Siegel, G. De Leo, F. Micheli, and A. Rosenberg. In press. The value of spatial information in MPA network design. Proceedings of the National Academy of Sciences of the United States of America.

Crowder, L., and E. Norse. 2008. Essential ecological insights for marine ecosystem-based management and marine spatial planning. Marine Policy 32:772-778.
Daily, G.C., T. Söderqvist, S. Aniyar, K. Arrow, P. Dasgupta, P.R. Ehrlich, C. Folke, A. Jansson, B.-O. Jansson, N. Kautsky, and others. 2000. The value of nature and the nature of value. Science 289:395-396.

Dasgupta, P., S. Levin, and J. Lubchenco. 2000. Economic pathways to ecological sustainability. Bioscience 50(4):339-345.

Diaz, R.J., and R. Rosenberg. 2008. Spreading dead zones and consequences for marine ecosystems. Science 321:926-929.

Dietz, T., E. Ostrom, and P.C. Stern. 2003. The struggle to govern the commons. Science 302:1,907-1,912.

Douvere, F. 2008 The importance of marine spatial planning in advancing ecosystem-based sea use management. Marine Policy 32:762-771.

Ehler, C., and F. Douvere. 2007. Visions for a Sea Change: Report of the First International Workshop on Marine Spatial Planning. Intergovernmental Oceanographic Commission and Man and the Biosphere Programme, IOC Manual and Guides 46, ICAM Dossier 3, UNESCO, Paris, France, 84 pp. Available online at: http://www.unesco-ioc-marinesp.be/ uploads/documentenbank/322a25f624fcb $940 \mathrm{dc}$ 70d0b3b510de24.pdf (accessed April 6, 2010).

Gaines, S.D., S.E. Lester, K. Grorud-Colvert, C. Costello, and R. Pollnac. In press a. The evolving science of marine reserves: New developments and emerging research frontiers. Proceedings of the National Academy of Sciences of the United States of America.

Gaines, S.D., C. White, M.H. Carr, and S.R. Palumbi. In press b. Designing marine reserve networks for both conservation and fisheries management. Proceedings of the National Academy of Sciences of the United States of America.

Grorud-Colvert, K., S.E. Lester, S. Airamé, E. Neeley, and S.D. Gaines. In press. Communicating marine reserve science to diverse audiences. Proceedings of the National Academy of Sciences of the United States of America.

Halpern, B.S. 2003. The impact of marine reserves: Do reserves work and does reserve size matter? Ecological Applications 13(1):S117-S137.

Halpern, B.S., and R.R. Warner. 2002. Marine reserves have rapid and lasting effects. Ecology Letters 5:361-366.

Halpern, B.S., S.E. Lester, and K.L. McLeod. In press. Placing marine protected areas onto the ecosystem-based management seascape. Proceedings of the National Academy of Sciences of the United States of America.

Hamilton, S.L., J.E. Caselle, D. Malone, and M.H. Carr. In press. Incorporating biogeography into evaluations of the Channel Islands marine reserve network. Proceedings of the National Academy of Sciences of the United States of America.
Heal, G., G.C. Daily, P.R. Ehrlich, J. Salzman, C. Boggs, J. Hellmann, and J. Hughes. 2001. Protecting natural capital through ecosystem service districts. Stanford Environmental Law Journal 20:333-364.

Heal, G., and W. Schlenker. 2008. Sustainable fisheries. Nature 455:1,044-1,045.

Hilborn, R., J.M. Orensanz, and A.M. Parma. 2005. Institutions, incentives and the future of fisheries. Philosophical Transactions of the Royal Society B 360:47-57.

Janssen, M.A., O. Bodin, J.M. Anderies, T. Elmqvist, H. Ernstson, R.R.J. McAllister, P. Olsson, and P. Ryan. 2006. Toward a network perspective of the study of resilience in socialecological systems. Ecology and Society 11(1):15

Kathiresan, K., and N. Rajendran. 2005. Coastal mangrove forests mitigated tsunami. Estuarine, Coastal and Shelf Science 65:601-606.

Kinzig, A.P., D. Starrett, K. Arrow, S. Aniyar, B. Bolin, P. Dasgupta, P. Ehrlich, C. Folke, M. Hanemann, G. Heal, and others. 2003. Coping with uncertainty: A call for a new science-policy forum. Ambio 32(5):330-335.

Leslie, H.M., and A.P. Kinzig. 2009. Resilience science. Chapter 4 in Ecosystem-Based Management for the Oceans. K.M. McLeod and H.L. Leslie, eds, Island Press, Washington, DC.

Lester, S.E., B.S. Halpern, K. Grorud-Colvert, J. Lubchenco, B.I. Ruttenberg, S.D. Gaines, S. Airamé, and R.R. Warner. 2009. Biological effects within no-take marine reserves: A global synthesis. Marine Ecology Progress Series 384:33-46.

Levin, S.A. 1998. Ecosystems and the biosphere as complex adaptive systems. Ecosystems 1:431-436.

Levin, S.A. 1999. Fragile Dominion: Complexity and the Commons. Perseus Publishing, Cambridge, MA, 272 pp.

Levin, S.A., and J. Lubchenco. 2008. Resilience, robustness, and marine ecosystem-based management. Bioscience 58(1):27-32.

Liu, J., T. Dietz, S.R. Carpenter, M. Alberti, C. Folke, E. Moran, A.N. Pell, P. Deadman, T. Kratz, J. Lubchenco, and others. 2007. Complexity of coupled human and natural systems. Science 317:1,513-1,516.

Love, M.S., P. Morris, M. McCrae, and R. Collins. 1990. Life history aspects of 19 rockfish species (Scorpaenidae: Sebastes) from the southern California bight. NOAA Technical Report NMFS 87.

Lubchenco, J. 1998. Entering the century of the environment: A new social contract for science. Science 279:491-497.

Lubchenco, J., S.R. Palumbi, S.D. Gaines, and S. Andelman. 2003. Plugging a hole in the ocean: The emerging science of marine reserves. Ecological Applications 13(1):S3-S7.

McCook, L.J., T. Ayling, M. Cappo, J.H. Choat, R.D. Evans, D.M. DeFreitas, M. Heupel, T.P. Hughes, G.P. Jones, B. Mapstone, and others. In press. Adaptive management of the Great Barrier Reef: A globally significant 
demonstration of the benefits of networks of marine reserves. Proceedings of the National Academy of Sciences of the United States of America.

McLeod, K., and H. Leslie, eds. 2009a. EcosystemBased Management for the Oceans. Island Press, Washington, DC, $392 \mathrm{pp}$.

McLeod, K., and H. Leslie, eds. 2009b. Why ecosystem-based management? Chapter 1 in Ecosystem-Based Management for the Oceans. K.M. McLeod and H.L. Leslie, eds, Island Press, Washington, DC.

McLeod, K., J. Lubchenco, S.R. Palumbi, and A.A. Rosenberg. 2005. Scientific Consensus Statement on Marine Ecosystem-Based Management. Signed by 221 academic scientists and policy experts with relevant expertise and published by the Communication Partnership for Science and the Sea, $21 \mathrm{pp}$. Available online at: http://www.compassonline.org/pdf_files/ EBM_Consensus_Statement_v12.pdf (accessed March 28, 2010).

Millennium Ecosystem Assessment. 2005. Ecosystems and Human Well-Being: Synthesis. Island Press, Washington, DC.

National Research Council. 1999. Our Common Journey. National Academy Press, Washington, DC, 384 pp.

National Research Council. 2008. Increasing Capacity for Stewardship of Oceans and Coasts: A Priority for the 21st Century. National Academies Press, Washington, DC, 156 pp.

Nelson, E., G. Mendoza, J. Regetz, S. Polasky, H. Tallis, D.R. Cameron, K.M.A. Chan, G.C. Daily, J. Goldstein, P.M. Kareiva, and others. 2009. Modeling multiple ecosystem services, biodiversity conservation, commodity production, and tradeoffs at landscape scales. Frontiers in Ecology and the Environment 7(1):4-11.

Ostrom, E. 2009. A general framework for analyzing sustainability of social-ecological systems. Science 325:419-422.

Ostrom, E., J. Burger, C.B. Field, R.B. Norgaard, and D. Policansky. 1999. Revisiting the commons: Local lessons, global challenges. Science 284:278-282.

Partnership for Interdisciplinary Studies of Coastal Oceans. 2007. The Science of Marine Reserves, 2nd ed. 21 pp. Available online at: http://www. piscoweb.org/outreach/pubs/reserves (accessed February 15, 2010)

Pelc, R.A., R.R. Warner, S.D. Gaines, and C.B. Paris. In press. Detecting larval export from marine reserves. Proceedings of the National Academy of Sciences of the United States of America.

Pew Oceans Commission. 2003. America's Living Oceans: Charting a Course for Sea Change. Pew Oceans Commission, Arlington, VA. Available online at: http://www.pewtrusts.org/our_work_ detail.aspx?id=130 (accessed April 5, 2010).

Pollnac, R., P. Christie, J.E. Cinner, T. Dalton, T.M. Daw, G.E. Forrester, N.A.J. Graham, and T.R. McClanahan. In press. Marine reserves as linked social-ecological systems. Proceedings of the National Academy of Sciences of the United States of America.

Pomeroy, R., and F. Douvere. 2008. The engagement of stakeholders in the marine spatial planning process. Marine Policy 32:816-822.

Rabalais, N.N., R.E. Turner, and D. Scavia. 2002. Beyond science into policy: Gulf of Mexico hypoxia and the Mississippi River. Bioscience 52(2):129-142.

Redstone Strategy Group LLC, and Environmental Defense Fund. 2007. Assessing the Potential for LAPPs in U.S. Fisheries. Available online at: http://redstonestrategy.com/ documents/2007-03-26\%20Assessing\%20 the $\% 20$ Potential\%20for\%20LAPPs\%20in\%20 US\%20Fisheries.pdf (accessed April 12, 2010).

Roberts, C.M., J.A. Bohnsack, F. Gell, J.P. Hawkins, and R. Goodridge. 2001. Effects of marine reserves on adjacent fisheries. Science 294:1,920-1,923.

Rosenberg, A.A., and K.L. McLeod. 2005. Implementing ecosystem-based approaches to management for the conservation of ecosystem services. Marine Ecology Progress Series 300:270-274.

Rosenberg, A.A., and P.A. Sandifer. 2009. What do managers need? Chapter 2 in Ecosystem-Based Management for the Oceans. K.M. McLeod and H.L. Leslie, eds, Island Press, Washington, DC.

Ruckelshaus, M., and A.D. Guerry. 2009. Valuing marine ecosystems? Marine Scientist 26:26-29.

Schellnhuber, H.J., P.J. Crutzen, W.C. Clark, M. Claussen, and H. Held. 2004. Earth System Analysis for Sustainability. Report on the 91st Dahlem Workshop. MIT Press, Cambridge, MA, $468 \mathrm{pp}$

Smith, M.D., J. Lynham, J.N. Sanchirico, and J.A. Wilson. In press. Political economy of marine reserves: Understanding the role of opportunity costs. Proceedings of the National Academy of Sciences of the United States of America.

Socolow, R.H. 1999. Nitrogen management and the future of food: Lessons from the management of energy and carbon. Proceedings of the National Academy of Sciences of the United States of America 96:6,001-6,008.

Steffen, W., A. Sanderson, P. Tyson, J. Jäger, P. Matson, B. Moore, F. Oldfield, K. Richardson, F. Oldfield, H.-J. Schellnhuber, B.L. Turner II, and R.J. Wasson. 2004. Global Change and the Earth System: A Planet Under Pressure. Springer-Verlag, New York, NY, 332 pp.

Tallis, H.M., and P. Kareiva. 2006. Shaping global environmental decisions using socioecological models. Trends in Ecology and Evolution 21(10):562-568

Tallis, H., and S. Polasky. 2009. Mapping and valuing ecosystem services as an approach for conservation and natural-resource management. Annals of the New York Academy of Science 1162:265-283.
Tallis, H., P. Kareiva, M. Marvier, and A. Chang. 2008. An ecosystem services framework to support both practical conservation and economic development. Proceedings of the National Academy of Sciences of the United States of America 105(28):9,457-9,464.

Turner, R.K., and G.C. Daily. 2008. The ecosystem services framework and natural capital conservation. Environmental and Resource Economics 39(1):25-35.

United Nations Environment Programme. 2006. Marine and Coastal Ecosystems and Human Well-Being: A Synthesis Report Based on Findings of the Millennium Ecosystem Assessment. United Nations Environment Programme, Nairobi, Kenya, 64 pp.

US Commission on Ocean Policy. 2004. An Ocean Blueprint for the $21^{\text {st }}$ Century. US Commission on Ocean Policy, Washington, DC. Available online at: http://oceancommission.gov/ documents/full_color_rpt/000_ocean_full_ report.pdf (accessed April 5, 2010).

US Global Change Research Program. 2009. Global Climate Change Impacts in the United States. Cambridge University Press, New York, NY. Available online at: http://downloads. globalchange.gov/usimpacts/pdfs/climateimpacts-report.pdf (accessed April 5, 2010).

Vitousek, P.M., H.A. Mooney, J. Lubchenco, and J.M. Melillo. 1997. Human domination of Earth's ecosystems. Science 277:494-499.

Walker, B., and D. Salt. 2006. Resilience Thinking: Sustaining Ecosystems and People in a Changing World. Island Press, Washington, DC, 192 pp.

Wood, L.J., L. Fish, J. Laughren, and D. Pauly. 2008. Assessing progress towards global marine protection targets: Shortfalls in information and action. Oryx 42:340-351.

Worm, B., E.B. Barbier, N. Beaumont, J.E. Duffy, C. Folke, B.S. Halpern, J.B.C. Jackson, H.K. Lotze, F. Micheli, S.R. Palumbi, and others. 2006. Impacts of biodiversity loss on ocean ecosystem services. Science 314:787-790.

Young, O.R., F. Berkhout, G.C. Gallopin, M.A. Janssen, E. Ostrom, and S. van der Leeuw. 2006. The globalization of socio-ecological systems: An agenda for scientific research. Global Environmental Change 16:304-316. 